\title{
THE DUKE OF SUSSEX'S IRISH MANUSCRIPT (RYLANDS IRISH MS 22)
}

One of the Irish-language manuscripts in the Rylands collection has a more exotic history than the others. Most derive from the library of Denis H. Kelly (1797-1877), of Castle Kelly, in Co. Roscommon, and many of those were made by him or commissioned for his collection. ${ }^{1}$ Few of his manuscripts are earlier than the middle of the nineteenth century. Rylands Irish MS 22, by contrast, is the work of a wellknown vernacular scribe who worked on the northern outskirts of Dublin between about 1710 and about 1730. As was often done by professional Irish scribes in this period, he signed and dated his work in a colophon: '1710:88 R. T. iarna sgriobhtha anois go nua le Riosdard Tuibear, 1710', '1710: 88 R. T. written now anew by Risteard Tuibear, 1710'. The manuscript carries one substantial text, Geoffrey Keating's devotional work, Trí Biorghaoithe an Bháis, conventionally rendered 'three shafts of death', though darts or stings would better capture the sense of sharp spears represented by the compound bior-ghaoithe. The label on the spine reads 'Keating Three Darts of Death. Irish MS', while inside the front board an older hand has written 'Keating's three shafts of Death'. Keating completed this work in 1631, and like his other major works it quickly gained wide circulation in manuscript. Many copies survive, but a critical text has been founded on two early witnesses. ${ }^{2}$ It is unlikely that collation would show Tuibear's copy to be textually important, but it represents the wide reception of Keating's work, which presented Tridentine Catholicism to an Irish audience. ${ }^{3}$ The end of the text, however, presents an interesting feature. At the top of p. 340 in the manuscript, we are in the Latin quotation from chapter 21 of Augustine's Soliloquia (line 10951 in Bergin's text), but a fair number of lines are omitted between there and the conclusion of the text on $p$. 341. Here, after the final Amen, the scribe has written a colophon, 'FINIS. Trocaire ó Dhía go bhfuighthe an sgiobhneóir [l. sgriobhneóir], .i. Riosdaird Tuibear : R. T.' ('May the scribe Risteard Tuibear get mercy from God'). On the next page the

1 Denis Kelly's library was auctioned in Dublin in 1875, Catalogue of the library of Denis H. Kelly [. . .] comprising numerous works of rarity of the history, antiquities, and language of Ireland [. . .] To be sold by auction, by John Fleming Jones [. . .] Thursday, 28th October [. . .]. Bernard Quaritch bought most of the manuscripts for the earl of Crawford, and his marked copy of the auction catalogue, now in Princeton UL, can be seen via Google Books. The Irish manuscripts in the Rylands collection were listed as if they had all come from Kelly, though without cross-matching with his sale, by Liam Mac Peaircín, Donnchadh Ó Ceallaigh, Fear freastail lucht léinn (Dublin, 2008), 80-115.

2 The standard edition is now Osborn Bergin, Trí Bior-Ghaoithe an Bháis, Séathrún Céitinn do sgríobh: The Three Shafts of Death, by Geoffrey Keating, DD, edited with introduction, indexes, and glossary (Dublin, 1931), based on two early copies, which 'generally agree word for word' (p. ix). His sources were TCD MS 1403 (H. 5. 32), written by Seán Ó Maoil Chonaire, 1645, which also includes a copy of Keating's Foras Feasa ar Eirinn, acquired by Sir James Ware, $1648 \times 1666$ (W. O'Sullivan, 'A findinglist of Sir James Ware's manuscripts', PRIA 97C (1997), 69-99, at p. 82); and RIA MS 23 O 13 (cat. 141, Hodges \& Smith 121), also written by Ó Maoil Chonaire, datable to 1643 (and twinned with a copy of Foras Feasa ar Eirinn, by the same scribe in the same year, now RIA MS 23 O 19, cat. 142, Hodges \& Smith 122).

3 Bernadette Cunningham, The World of Geoffrey Keating. History, myth, and religion in seventeenthcentury Ireland (Dublin, 2000), 43-58. 
closing lines of the text resume at the words, 'Má do-bheir tú tiodhlaicthe <doáirmhe> éagsamhla dhúinn anois' (line 10957) and continue again to the end. This time after the final Amen, the scribe has written his second, dated, colophon, including the words 'iarna sgriobhtha anios go nua le Riosdard Tuibear' ('now written anew by Risteard Tuibear'). The date of the primary copying may be somewhat earlier than 1710 - the hand has a different appearance - and the last page or so was written anew, whether to correct his own omission or from a more perfect exemplar. This stands at the start of Tuibear's documented career. For twenty years he was part of a scribal network around Dublin that could and did support the circulation of major works in Irish around Ireland.

At the front of the manuscript the Lindsay book-plate shows that this is one of the large collection of manuscripts bought by Mrs Rylands from the 26th earl of Crawford in 1901. This book-plate slightly overlies an earlier book-plate, which carries no name but includes an elaborate shelfmark and a ducal coronet. It is easily identified as that of H. R. H. Prince Augustus Frederick (1773-1843), Duke of Sussex, sixth son of King George III and a major book-collector, whose large library was centred around copies of the Bible in many languages. External evidence allows the history of the manuscript to be extended.

The scribe Risteard Tuibear is well known, because a fair number of examples of his work have survived. He often worked with other Dublin scribes in the early eighteenth century, among whom the names of Seán Ó Neachtain and his son Tadhg Ó Neachtain stand out as both writers and scribes. The Ó Neachtain circle has been much studied through their books, and these books for the most part survived in the hands of Muiris Ó Gormáin, who died in Dublin in 1786 or 1787. In 1761 Muiris made a list of his books; his list names 'Mr Tipper' as the scribe in ten cases, and when other entries are cross-matched with surviving books four more in Tuibear's hand can be added. More than one fifth of Muiris's collection was made by this one scribe from the previous generation. The manuscripts that remained in Muiris's possession at the time of his death passed to one Henry Wright, who sometimes entered his name in books as Enri Mac an tSaoir and who began to practise copying for himself. On his leaving Ireland in, it is said, 1794, the books became the property of Edward O'Reilly. ${ }^{4}$ From about 1806 until his death in August 1830, Edward O'Reilly was able to present himself as an expert on Irish manuscripts and indeed on the language itself, though he was no native speaker. None the less he did important work. Still useful is A Chronological Account of Four Hundred Irish Writers (1820), based in large part on his own library. A considerable number of manuscripts from Muiris Ó Gormáin's collection remained in O'Reilly's hands to the time of his death. He made a catalogue of his manuscripts in 1825 , which served as the basis for the sale catalogue when the books were auctioned in October 1830. It can also be

4 This group of manuscripts was first explored by Robin Flower in his introduction, written in the 1920s and after, to the third volume of Catalogue of Irish Manuscripts in the British Museum (London, 192653). I have in hand a study of the formation and dispersal of this collection as part of a book on Irish manuscript sales, which I have drawn on here and which will include annotated texts of the relevant sale catalogues. 
established that O'Reilly had sold a fair number of manuscripts before 1825, and many of these can also be traced.

Three lists have also survived, describing books in Muiris Ó Gormáin's possession at different dates, 1761, 1772, and 1776, together with fragments of other lists which he scrapped when they were superseded. We do not know exactly how these lists have come down to us, but their testimony is enormously valuable for their rich witness to a scribe's working library. ${ }^{5}$ In the first of them Ó Gormáin has entered a copy of Keating's Trí Biorghaoithe: ${ }^{6}$

Tri biorghaethi an bháis or the 3 shafts of death on paper in a large quarto bound, containing 346 pages, or 43 sheets and a half at $61 / 2$ per sheet comes to $£ 1 . .3 . .61 / 2$ and wrote by Mr Tipper.

Already bound in 1761, the book retains its early eighteenth-century binding. Muiris was a scribe himself, and he valued his book on the basis of the price of copying per quarto sheet. Another, fragmentary, list has a briefer entry: ${ }^{7}$

Tri bior gaoithe an báis written by Rd Tipper, 1710, 4to.

In one case the number of pages and the scribe, in the other the year and the scribe, match the Rylands manuscript, which has come down from this Dublin circle of scribes to Muiris Ó Gormáin. A third list, dated 1772, may refer to the same book: ${ }^{8}$

Trí biorgaethe an bhais, a 4to bound, about 3 Quire of paper.

Three quires of paper would amount to much more than $43 \frac{1}{2}$ sheets, but 'about' shows that he was guessing from thickness rather than counting leaves. No other copy of this work appears in the complementary lists from 1772 and 1776.

If the book remained with Ó Gormáin until his death, it is very likely that it came into the keeping of Edward O'Reilly, but there is nothing to prove this, and some small reason to think it may not be the case.

We know that the book was in the library of the Duke of Sussex in 1827, when the first instalment of a catalogue was published under the title Bibliotheca Sussexiana. This was compiled by the duke's surgeon and librarian, Thomas Joseph Pettigrew (1791-1865), and in it we find Keating's Three Shafts: ${ }^{9}$

5 The 1761 list is in RIA MS 23 H 23 (cat. 631), whose history is not known. NLI MS G664 (accessioned in 1954), which preserves the lists dated 1772 and 1776, was previously a part of RIA MS Stowe I. v. 1 (cat. 745), though it was not part of the core of the Stowe collection, the books of Charles O'Conor of Belanagare; R. Sharpe, 'Muiris Ó Gormáin's book-lists and T. F. O'Rahilly', Celtica 27 (2013), 114-18.

61761 Ó Gormáin 12 . The list was partially printed by Lesa Ní Mhunghaile, 'An eighteenth-century Gaelic scribe's private library: Muiris Ó Gormáin's books’, PRIA 110C (2010), 239-76, who identifies this item as Rylands Irish MS 22 with a query (p. 270). The query can be resolved.

7 A few entries from this list can still be read, with no date, inside the back of NLI MS G664.

81772 Ó Gormáin 19.

9 Bibliotheca Sussexiana. A descriptive catalogue [. . .], Vol. 1, part 1 (London, 1827), pp. cclxv-cclxvi. 
KeAting (Geoffrey) The Three Shafts of Death. Ms. IN THE Irish Language, ON PAPer. SAeC. XVII. Quarto.

One hundred and seventy-four leaves. Eight inches by six. This Ms. is very distinctly written, and divided into three books. There are two leaves of table. It contains various Latin quotations, several of which are taken from Scripture. I regret that I am unable to give any particular account of this Ms., being entirely ignorant of the language in which it is written. It was presented to His Royal Highness by my friend Sir W. Betham, Ulster King at Arms.

He adds a paragraph from secondary sources about Geoffrey Keating to take the description on to a second page. As it happens there also survive some letters between Pettigrew and his friend Sir William Betham (1779-1853), who had worked as a herald and genealogist at the Office of Arms in Dublin since 1807. The crucial letter was noted long ago by Beryl Phair in the copybook of Betham's out-letters from the year 1826, though she knew nothing of Ó Gormáin's lists or of the book in the Rylands collection. ${ }^{10}$ Her subject was Betham's own manuscript collections, and his connexion with the royal duke attracted her notice. Perhaps Betham hoped that he might himself attract the notice of His Royal Highness: the more unusual gift of an Irish book-shrine has been reported but not documented. ${ }^{11}$ Now, between 1818 and 1828 Betham had frequent contact with Edward O'Reilly, who for some years held clerical positions in Dublin Castle, while in . Betham may have acquired manuscripts from O'Reilly around 1820, though I have not found evidence to show that he did so. At this period Betham's interest in Irish-language manuscripts was small, though he was ready to buy when he saw the opportunity to turn a profit. Phair noted his readiness to pay $£ 10$ for a manuscript around this time, which is far more than Tuibear's 1710 copy of Keating would have been likely to fetch in the Dublin salerooms at this date. ${ }^{12}$ It seems likely that what happened was that Pettigrew was

10 P. B. Phair, 'Sir William Betham's manuscripts', Analecta Hibernica 27 (1972), 1-99 (at p. 14), citing National Library of Ireland, MS GO 368, 4 November 1826. Other correspondence is now among Pettigrew's letters in the Beinecke Library, Box 1, Folder 51: a letter from Betham to T. J. Pettigrew, dated 1 June 1826, when Betham was in London, refers to his seeking an Armenian Testament for the duke's collection; in this case too, Pettigrew mentions Betham's role in his description of the Four Gospels in Armenian, Bibliotheca Sussexiana, pp. cclxxv-cclxxvi.

11 This object, now in the National Museum of Ireland, is known as the Miosach. Betham put it up for auction with Evans of Pall Mall, 6 July 1830, but, like several manuscripts in that sale, it did not reach a price that satisfied him and was bought in. The manuscripts went back to Dublin. The Miosach finally returned to Ireland, it is said, in 1843. J. H. Todd, who exhibited the shrine at the Academy, 13 June 1853, to illustrate his talk, 'On ancient Irish reliquaries', PRIA 5 (1850-53), 461-7, reports that Betham gave this book shrine to the duke of Sussex , 'and it was afterwards sold in London, at an auction, to Mr Rodd, an eminent London bookseller' (p. 466). Thomas Rodd brought it to the attention of Dr Todd, who happened to be in London and who bought it for £20, bringing it it back to Dublin. I have been unable to authenticate this story. On 26 April 1843 the Míosach featured as 'a genuinely authenticated relic of St Columba' in the opening ceremony of Lord Adare's new college at Stackallen, Co. Meath (G. O. Simms, 'James Henthorn Todd', Hermathena 109 (1969), 5-23, pp. 17-18, citing TCD MS Todd 140). The duke of Sussex died on 21 April 1843, which does not allow time for the events described unless the duke had chosen to dispose of the object some time before. At the time of Todd's discourse William Betham was still alive and a member of the RIA, but the proceedings do not record whether he was present.

12 Phair, 14, reports how Betham was seeking a manuscript from Eoghan Caomhánach in Limerick in 1826, buying it for $£ 10$ through someone named Martin Creagh in Limerick (Phair, 14). Phair thought it was a copy of St John's gospel with copious annotations, which Betham came to own. That twelfth-century Latin book is now BL MS Add. 8091 (1830 Betham 436), part of a medieval composite divided up by 
keen to have an Irish manuscript for the duke's library, perhaps ideally an Irish bible, though such did not circulate in Catholic Ireland. If Betham set out to provide him with a book in 1826, then he did not buy this one from O'Reilly, who had already drawn up his catalogue in 1825, and there is nothing in it that did not go to auction in 1830. O'Reilly had a copy of Trí Biorghaoithe an Bháis on its own, imperfect at the beginning, as well as a copy with Keating's other works. ${ }^{13}$ If, on the other hand, Betham had owned the book for a few years, then it is not impossible that he had bought it from O'Reilly.

It is not possible, however, to rule out other routes of descent. Muiris Ó Gormáin may have parted with this book between 1772 and his death, leaving it in other hands and potentially on the market in Dublin some fifty years before Betham had the reason to buy it. Inside the front board, we have already mentioned the title in English, which could be in Ó Gormáin's hand. It was modified by the addition of Keating's forename Geoffrey and the words 'in the Irish language' at some point, and there is also a number in ink, 'No. 11', which is unexplained. It may represent an unknown early sale, though it does not correspond to manuscripts in the only two known sales of Irish manscripts in this period, auctioning the libraries of Fr Paul O'Brien in 1821 and of John MacNamara in 1822.

This copy of Keating's Three Shafts reposed less than twenty years in the duke's library at Kensington Palace. After the duke died in 1843, his library was auctioned in six sales over many days by Evans, of Pall Mall, between July 1844 and August 1845. In the first part of the sale, devoted to theology, there was a printed New Testament in Irish from 1602 (lot 1417), a bible from 1685 (lot 896), a psalter from 1694 (lot 1247), and several modern biblical editions (lots 1313-15, 1810-11). In the second part, still 1844 and devoted to more than five hundred manuscripts, we find at lot 15:

Botany. A MS on Botany, in the Irish language and character, ON VELLUM. Size 43/4 Inches by 3.

This book of materia medica is now BL MS Add. 15403 (O'Grady, i. 222-31), some seventy leaves written in the sixteenth century. Two notes at the front explain its presence: 'Presented by Sir Wm. Betham May 24th 1827-MS. on Botany in the Irish character'; 'Purchased at the Sussex Sale 31st July 1844 by Thorpe and of him (through Rodd) for BM 10 Aug. 1845'. Once again it was Betham who supplied an Irish book for the duke's library, and once again it is not known how he got it in the first place. This book was bought at auction by the dealer Thomas Thorpe and sold on

Betham ahead of his auction in 1830. It seems highly unlikely that this was ever in Caomhánach's hands. Yet it is also not very likely that Ó Gormáin's manuscript came into Caomhánach's hands in Dublin and was taken to Limerick. $£ 10$ would have been a high price for our manuscript in Ireland in 1826, but whatever Caomhánach had was probably Irish. We have evidence, therefore, of Betham's handling several Irish manuscripts in the same year.

131830 O'Reilly 192 was a quarto-sized copy of Keating's Three Shafts, imperfect at the beginning, which sold for only $2 /$ - to someone who bought only at the lower end of the price-scale and has not been traced. 1830 O'Reilly 102 contained both of Keating's religious works as well as other texts. It went to a Dublin bookseller for 18/6 before being sold to Sir Thomas Phillipps; it is now NLI MS G55. 
to the British Museum by another dealer Thomas Rodd Jr. And then at lot 283, our copy of Keating's Three Shafts appears:

Keating's (Jeffrey) Three Shafts of Death. Manuscript in the Irish language and character, dated 1710 .

Named copies of the sale catalogue confirm that lot 15 went to Thomas Thorpe for $10 /-$ and show that lot 283 was also bought by Thorpe for $£ 18$ s $0 \mathrm{~d}$. Tracing its passage in the trade may take more time than the added knowledge is worth, but John Hodgson, studying the 25th earl of Crawford's collecting of manuscripts, has discovered that it was item 45 among the European Manuscripts at the front of Quaritch's General Catalogue, No. 231, in 1866, and still item 45 in his General Catalogue, June 1868:

Irish. Tri Bior-gaothe an Bhais, re Seuthrun Ceitin: the Three Darts of Death, by Geoffrey Keating, author of the History of Ireland, sq. 8vo, very meat MS. 341pp. from the library of the Duke of Sussex, old calf, £2 16s. Copied by Richard Tubber, 1710.

And in almost the same words again in his catalogue No. 243, March 1869, item 60, when a further line added 'This MS was originally presented by Sir William Betham to the Duke of Sussex'. The earl was buying hundreds of books every year from Quaritch. If he ever read Pettigrew's catalogue of the duke's library, he would have learnt that Betham was the intermediary who sent the book from Ireland. He surely did not know that this book came from a fine scribal stable, any more than Risteard Tuibear or Muiris Ó Gormáin would have imagined Keating's Three Shafts in the libraries of His Royal Highness or the earl of Crawford. ${ }^{14}$

\author{
R. SHARPE \\ Faculty of History, Oxford
}

14 My thanks first to John Hodgson, who provided images allowing me to confirm the match made in this paper and added his own finding from Quaritch's catalogues. Also to Dr William Stoneman and Dr Peter Kidd for their help with the sale catalogues of Bibliotheca Sussexiana, while I was writing in Ireland; there is a named and priced copy of this catalogue in JRUL. 